\title{
IMPACT OF MOBILE PHONES AND INTERNET USE ON FINANCIAL INCLUSION: EMPIRICAL EVIDENCE FROM THE EU POST-COMMUNIST COUNTRIES
}

\author{
Yilmaz BAYAR (D) 1 , Marius Dan GAVRILETEA (102*, Dragoş PĂUN(®3 \\ ${ }^{1}$ Department of Public Finance, Faculty of Economics and Administrative Sciences, \\ Bandirma Onyedi Eylul University, Bandirma/Balıkesir, Turkey \\ ${ }^{2,3}$ Department of Business, Faculty of Business, Babes-Bolyai University, Cluj-Napoca, Romania
}

Received 17 February 2020; accepted 11 January 2021

\begin{abstract}
Poverty alleviation has become one of the biggest challenges for many countries and access to financial services is considered to be a key driver of development and economic growth. Finding solutions that can break down barriers that poor people are facing to access formal financial services has become a major concern for researchers, governments, financial institutions. Financial services must reinvent themselves and the adoption of new technology is a crucial key to overhaul their operations and to find innovative solutions to manage customer expectations. The escalation in access and penetration level of mobile phones and the Internet can improve financial inclusion by facilitating easy access to financial services, by providing secure transaction platforms, by reducing transaction costs, by providing a competitive business framework.

There has been relatively limited research on the impact of Internet and mobile phones use on financial inclusion, therefore our main purpose was to investigate this linkage in a sample of 11 post-communist countries of the European Union from 1996-2017 using panel cointegration and causality analyses. Firstly, we investigated whether mobile cellular phone subscriptions and the rate of Internet usage affect financial institutions' access; secondly, we analysed the impact of these variables on financial market access. Results indicate that mobile cellular phone subscriptions positively affect both financial institution access in countries like Hungary, Latvia, Lithuania, Poland, and Slovenia and financial market access in Bulgaria, Croatia, and Hungary. Also, a negative relationship between mobile cellular phone subscriptions and financial institution access was noticed in the Czech Republic and regarding financial market access in the Czech Republic and Poland. Our findings also indicate both positive and negative relationships between Internet usage rates and financial institutions and financial markets access. By increasing Internet usage we can improve access to financial institutions in Bulgaria, Croatia, Czech Republic, Hungary, and Poland and we can increase financial markets access in Latvia and Slovenia.
\end{abstract}

Keywords: financial inclusion, mobile phones and Internet use, panel cointegration and causality analyses.

JEL Classification: F36, O30, O33, G20, L96.

${ }^{\star}$ Corresponding author. E-mail: marius.gavriletea@ubbcluj.ro

Copyright (c) 2021 The Author(s). Published by Vilnius Gediminas Technical University

This is an Open Access article distributed under the terms of the Creative Commons Attribution License (http://creativecommons. $\mathrm{org} / \mathrm{licenses} / \mathrm{by} / 4.0 /$ ), which permits unrestricted use, distribution, and reproduction in any medium, provided the original author and source are credited. 


\section{Introduction}

Our global economy, our societies, our lives are continuously transformed and reshaped driven by the progress in the information and communication technology (ICT) sector. As globalization has intensified, connectivity creates a paradox, filling the gaps within individuals based on geographical location, family background, sex, level of income, gender, income' level, etc. but at the same time causing loneliness and isolation. Besides negative aspects, connectivity enables people and companies to access information, facilitate communications and creates new business opportunities. ICT connectivity provides communication channels that can accelerate technology transfer, improve trade and international competition, and foster socio-economic inclusion.

ICT diffusion influences economic and financial development (Farhadi et al., 2012; Toader et al., 2018; Alshubiri et al., 2019) and will continue to shape the future of our society by changing the ways how people are connected and communicate one to each other, by eliminated geographical borders between nations and bringing societies close to each other (Naikoo et al., 2018), by reducing cultural differences (Kulesz, 2016).

Rapid technological changes have spurred financial innovations that have fundamentally changed traditional financial services and products. Old models used to develop and deliver financial services or products have been replaced with new ones to improve financial sector efficiency and effectiveness, to increase customers' access and to reduce costs, etc. These changes play a pivotal role in advancing financial inclusion (Andrianaivo \& Kpodar, 2012; Asongu, 2013; Kirui et al., 2013; Bhuvana et al., 2016; Bisht \& Mishra, 2016; Chatterjee \& Anand, 2017; Lenka \& Barik, 2018).

In recent years financial inclusion has reached the attention of researchers and policymakers for several reasons. Firstly, financial inclusion plays a significant role in economic growth (Sharma, 2016; Bose et al., 2018; Toader et al., 2018), secondly, can be a useful tool for ensuring social inclusion (Bold et al., 2012; Trivelli, 2013); thirdly, is seen as a key enabler for transforming poverty into prosperity (Majeed, 2017; World Bank, 2018; Hussaini \& Chibuzo, 2018; Omar \& Inaba, 2020); fourthly, is considered to be a major contributing factor to achieving United Nations Sustainable Development Goals (Sahay et al., 2015; Klapper et al., 2016; United Nations Capital Development Fund, 2020).

All over the world people and companies need to have affordable and easy access to financial services and products. For developing countries, where basic resources like clean water, fresh air, or other basic facilities are still lacking it is a major challenge to assure easy access to current or savings accounts, credits, transfers services, insurance products, etc. Expanding access to financial services especially in the poorest areas can help people to reduce inequalities and to escape from poverty. At first glance, we can consider that financial exclusion affects in particular people from developing countries but surprisingly different studies indicate that developed countries face the same problem (Washington, 2006; Barboni et al., 2017; House of Lords, 2017). Obstacles like high fees for transactions, for opening or maintaining accounts, high minimum balance requirements, high collateral requirements, laborious documentation required for various operations, infrastructural constraints contribute to a persistent percentage of people who are financially excluded even in developed countries. 
Providing essential financial services to both vulnerable population and small companies, "at an affordable cost in a fair and transparent manner" (Irving Fisher Committee, 2015) without compromising financial stability (Dittus \& Klein, 2011), efficiency or competitiveness is a global challenge involving not only developing countries but also the developed ones.

Taking into consideration that in 2017, around the world 1.7 billion adults were unbanked (World Bank, 2017), the introduction of modern technologies have a great contribution in lowering the cost of financial services, increasing the customers' confidence, spurring digital involvement and reducing physical interaction, enhancing in these ways the access and usage of financial services and contributing substantially to financial inclusion.

The impact of the expansion of mobile cell phones and Internet access on the financial services industry has been intensively analysed in the last years but the influence on financial inclusion was in generally neglected. There are a few studies that focused on the impact of mobile cell phones and Internet use on financial inclusion, most of them being conducted in underdeveloped and developing countries like Cambodia (Seng, 2017), Zimbabwe (Thulani et al., 2014), Rwanda (Van der Wansem, 2013), Sudan (Ammar \& Ahmed, 2016), Malawi (Mtambalika et al., 2016), 44 African countries (Andrianaivo \& Kpodar, 2012; Lundqvist \& Erlandsson, 2014), India (Kopala, 2010; Vadavadagi \& Allagi, 2014), Bangladesh (Sultana \& Khan, 2016), South Asian Association for Regional Cooperation (SAARC) countries (Lenka $\&$ Barik, 2018). Most of the empirical evidence emphasis that wide use of mobile phones and Internet use expand the access to and use of financial services.

Since the majority of previous studies focused on underdeveloped and developing countries, we have decided to fill the gap in the literature by investigating a sample of $11 \mathrm{EU}$ post-communist countries and to look at the impact of mobile phone and Internet use and access to financial institutions and financial markets. We covered the period between 1996 and 2017 and our analyses was relied on the Westerlund and Edgerton (2008) cointegration test with structural break and Dumitrescu and Hurlin (2012) causality test regarding the cross-sectional dependence among the countries and the financial crises in the study period. In this context, our paper contributes to the relevant literature in two dimensions: firstly, it is one of the early papers researching the impact of mobile phones and Internet use on financial inclusion focusing on a sample of 11 post-communist countries; secondly, the methodology used should provide more robust results given the heterogeneity and cross-sectional dependence of the sample.

We have selected these particular countries based on the fact that in the last decades they experienced the transition process from centrally planned economies to market economies and from a communist socio-political model to a liberal democratic model (Romaniuk \& Szromek, 2016). Countries started their transition process from a relatively same position and even some similarities can be found in this process, fundamental differences can also be noticed. The decline of communism helped these countries to restructure the economic and political system, to start the process of integration into the global market economy but each country followed distinct paths and strategies to economic development therefore different aspects of the economy tend to vary across countries.

Referring to the financial development we can group countries in 2 categories: countries from Central Europe (the Czech Republic, Hungary, Poland, Slovakia and Slovenia) and the 
Southeastern European and Baltic countries (Bulgaria, Romania, Croatia, Estonia, Latvia and Lithuania), the first category considered to have a more developed financial system (Caporale et al., 2015). Both categories of countries are facing the problem of financial exclusion but some countries are more exposed than others to this phenomenon.

According to the Global Findex database, in 2016 approximately $39.2 \%$ of adults were unbanked in Romania, 37\% in Bulgaria, 27.7\% in Hungary, compared to 2.8\% in Slovenia, 9.8\% in Latvia, $17.8 \%$ in the Czech Republic (World Savings and Retail Banking Institute, 2016). The causes of financial exclusion for these countries are multiple: low-income levels, high unemployment rates, low levels of education, poor living conditions mainly in small towns and rural areas (Meskoub, 2018). Poverty and financial exclusion are closely associated therefore richer countries are expected to face low levels of financial exclusion but surprisingly, high rates are also noticed in high-income countries (Barboni et al., 2017) therefore studies related to financial inclusion and its determinants are also necessary for this category of countries.

The paper has the following structure: Section 1 summarizes the empirical literature that investigated the relationship between mobile phones and Internet use and financial inclusion, Section 2 describes the dataset used and the proposed method, Section 3 presents the main findings and finally, Section 4 briefly indicates concluding remarks, future research recommendations but also some policy implications.

\section{Literature review}

The extraordinary progress in information and communication technologies and consequently the digital revolution that has been noticed in all sectors in the last years helped financial services to enter into the digital age (Alt et al., 2018). Development of mobile phones, mobile applications, personal computers, debit or credit cards and expansion of internet access reduced physical barriers between customers and financial companies and increased the access of different categories of population, companies to financial services and products (Gosavi, 2018).

Together with conducive policies and regulations, organization and implementation mechanism, supportive information technology and infrastructure is considered to be one of the three foundations of financial inclusion pillars (Kang, 2018).

Financial inclusion implies that people and companies can access formal financial services like transactions, payments, savings, credits, deposits, insurance, etc. at an affordable cost. In the last years, weve noticed significant changes in the number of mobile phone users and on mobile phone addiction behavior that facilitated branchless banking's development and improved financial inclusion. A growing share of people using mobile phones combined with a wide range of online financial services (Internet banking, electronic money transfers, trading platforms etc.) improved significantly the access to basic financial services and products for people that faced financial exclusion.

Many researchers explored the determinants of financial sector development, but relatively a small number of studies have explored the determinants of financial inclusion. In this context, studies generally have centered on studying the impact of specific factors that affect financial inclusion such as gender, age, income, education, household size, employment sta- 
tus, marital status, trust level in financial institutions (Soumaré et al., 2016; Tchamyou et al., 2019a, 2019b), interest rate, bank size and efficiency (Uddin et al., 2017), financial literacy, innovation or infrastructure (Akileng et al., 2018; Grohmann et al., 2018). Despite the significance of the ITC and financial inclusion relationship, there are very few studies that have focused on this relation, therefore is a clear need for additional studies.

A significant part of the population is excluded from access to formal financial services based on different reasons: costs, distance, lack of trust, bureaucracy, etc. (World Bank, 2018) and some of these barriers can be overcome through the development of ICT. According to the 2017 Global Findex database, globally, 69 percent of the adult population owned an account or had access to a mobile money provider (Center for Financial Inclusion, 2018).

Efforts towards achieving financial inclusion have been made over time including: extending bank branches in rural unbanked areas, adjusted interest rates granted to low-income households (Lenka \& Barik, 2018) but lately, global expansion of the Internet and mobile phone coverage combined with the development of branchless banking services and mobile financial services platforms and providers played a major role in fostering inclusion.

Different studies indicate that the expansion of mobile phones and Internet use have the potential to promote financial inclusion (Andrianaivo \& Kpodar, 2012; Chatterjee \& Anand, 2017; Seng, 2017; Bongomin et al., 2018; Lenka \& Barik, 2018, Chinoda \& Kwenda, 2019) which in turn will drive to the financial sector development (Rasheed et al., 2016; Anarfo et al., 2019).

Internet and mobile phones have become useful tools for promoting financial inclusion but also for the development of the financial sector by reducing the costs of financial services, raising the efficiency and working flexibility of the financial institutions (Alshubiri et al., 2019; Asongu \& Nwachukwu, 2019; Edo et al., 2019), providing access to formal financial services (Asongu, 2015), reducing the information asymmetry through information sharing (Aminuzzaman et al., 2003; Asongu \& Moulin, 2016; Asongu \& Nwachukwu, 2019) reducing income inequalities (Asongu \& Odhiambo, 2017; Asongu et al., 2018).

Andrianaivo and Kpodar (2012) conducted a study in African countries and found a positive and significant correlation between financial inclusion and mobile phone penetration rates. Using a panel dataset of 61 lower and middle-income countries Mushtaq and Bruneau (2019) reached a similar conclusion, that mobile phone penetration can promote financial inclusion.

Arvidsson (2014) investigated consumer attitudes towards mobile phone payments in a study that included Swedish consumers and founded that the adoption of a new payment system is linked to perceived ease of use, age, income, trust, perceived security risks. Security is considered to be a major issue in mobile payment and studies have shown that attackers could have access to customer's accounts due to server security vulnerabilities (Haupert et al., 2017).

Based on a study conducted in Cambodia, Seng (2017) pointed out that mobile phones have a positive impact on formal and informal borrowing. Another study conducted by Lenka and Barik (2018) in the South Asian Association for Regional Cooperation (SAARC) countries provided evidence of a positive association between the growth of mobile and Internet and financial inclusion. 
Bongomin et al. (2018) identified that social networks, mobile money usage have an important effect on financial inclusion in rural Uganda. Another analysis conducted by Chatterjee and Anand (2017) on a data set of 41 developed and developing countries found a significant positive relationship between ICT indicators and financial inclusion and pointed out that ICT development can be used as an instrument to enhance financial inclusion level. Their study provides us a helpful remark related to the role of mobile phones in promoting financial inclusion: a specific period of time (approximately two years) is necessary after the number of mobile phone subscriptions is increasing in order to lead to an increased level of financial inclusion. Also, they stated that the positive effect of mobile phone on financial inclusion is reached when is associated with adequate Internet facilities.

A more recent study conducted by Chinoda and Kwenda (2019) used a sample of 49 countries for the periods 2004-2016 and found a unidirectional causality from financial inclusion to mobile phones.

Mwangi (2017), CEO of Equity Bank, drew attention to the fact that financial inclusion implies not only money transfer facilities but also access to investments and insurance products, loans, savings.

Reviewing prior researches, we have noticed that most studies have focused mainly on developing countries from Africa and Asia (Andrianaivo \& Kpodar, 2012; Scott, 2014; Lapukeni, 2015; Seng, 2017; Lenka \& Barik, 2018; Bongomin et al., 2018; Chinoda \& Kwenda, 2019) and results clearly indicate that development of mobile phones and Internet use contributes to greater financial inclusion. There are no studies related to this subject in post-communist EU countries, therefore, to fill the gap and to contribute to the existing literature we will investigate this impact.

EU countries confronted in the last few years with an increasing number of migrants and refugees and in this context specific measures that can ensure access to basic financial products and services must be adopted. Knowing the influence that the expansion of mobile phones and Internet use can play in dealing with the issue of financial inclusion, can help both financial companies and legal authorities to provide affordable and easy access to different financial products and services.

\section{Data and econometric methodology}

The study explored the impact of mobile phones and Internet use on financial inclusion in 11 post-communist EU economies over the period 1996-2017 by applying panel cointegration and causality tests.

\subsection{Data}

In our research, we considered two different measures of financial inclusion, namely: access to financial institutions and access to financial markets both calculated by IMF (2019). Financial inclusion can be measured through access indicators (such as bank offices or branches or point of sale (POS) devices, etc.), usage indicators (such as average savings balances, number of transactions per account, number of electronic payments, etc.), and quality measures (World Bank, 2015). In this context, the financial institutions access index is calculated by 
bank branches per 100,000 adults and ATMs per 100,000 adults and financial markets access is measured through percent of market capitalization outside of the top 10 largest companies and the total number of issuers of debt indicating the development levels of stock and debt markets (Svirydzenka, 2016). The two indexes are evaluated to proxy both individuals' and firms' access to the financial system and many scholars have employed similar indicators for financial inclusion (e.g. see Sethi \& Acharya, 2018; Siddik et al., 2019; Maune et al., 2020).

We must specify that there is not a single indicator that can capture accurately the multidimensional concept of financial inclusion therefore researches conducted until now used different indicators in their analyses, but no matter which indicator was used, most findings indicate that mobile phone and Internet development foster financial inclusion.

Andrianaivo and Kpodar (2012) used two indicators to measure financial inclusion: number of deposits or loans per head and found a positive and significant relationship between mobile penetration and these two indicators.

Seng (2017) used borrowing indicators as proxy variables for financial inclusion and reached the same conclusion that mobile phones use helped to enhance financial inclusion.

Principal component analysis has been applied by Lenka and Barik (2018) to create a multidimensional financial inclusion index that combines six indicators of financial inclusion and results confirm that mobile and Internet usage growth has a positive impact on financial inclusion.

Chinoda and Kwenda (2019) also used in their analyses a multidimensional financial inclusion index (FII), and concluded that causality runs from financial inclusion to mobile phones.

Furthermore, mobile phone penetration was represented by mobile cellular subscriptions per 100 people and Internet penetration by individuals using the Internet (\% of the population) (World Bank, 2019a, 2019b) (Table 1).

Our sample consists of eleven post-communist EU countries, namely: Estonia, Latvia, Lithuania, Slovakia, Czech Republic, Poland, Bulgaria, Romania, Hungary, Croatia, and Slovenia. The econometric analyses were conducted using Stata 14.0 and Gauss 10.0. The summary characteristics of the dataset are presented in Table 2.

Table 1. Data description

\begin{tabular}{|l|l|l|}
\hline \multicolumn{1}{|c|}{ Variables } & \multicolumn{1}{c|}{ Description } & \multicolumn{1}{c|}{ Source } \\
\hline FIA & Index of financial institutions access & IMF (2019) \\
\hline FMA & Index of financial markets access & \\
\hline MOBILE & Mobile cellular subscriptions (per 100 people) & World Bank (2019a) \\
\hline INTERNET & Individuals using the Internet (\% of population) & World Bank (2019b) \\
\hline
\end{tabular}

Table 2. Summary statistics of the dataset

\begin{tabular}{|l|c|c|c|c|}
\hline \multicolumn{1}{|c|}{ Variables } & Mean & Std. Deviation & Minimum & Maximum \\
\hline FIA & 0.531140 & 0.194708 & 0.149185 & 0.937509 \\
\hline FMA & 0.190266 & 0.244387 & 0.003280 & 0.961747 \\
\hline MOBILE & 83.67447 & 49.30959 & 0.074543 & 164.0836 \\
\hline INTERNET & 42.00745 & 27.74822 & 0.221623 & 88.40970 \\
\hline
\end{tabular}


The financial institution access is very high when compared with financial markets access in our sample. Furthermore, a significant variation in both mobile cellular subscriptions and the share of individuals using the Internet in the population was found.

\subsection{Econometric methodology}

To address the general objective of this study we investigated the short-run and long-run dynamics between mobile phones and the Internet and financial inclusion by employing causality and cointegration tests. The causality analysis allows us to analyze the reciprocal interaction among the variables. In this context, pretests of cross-sectional dependence and homogeneity are applied to reveal whether we use first or second generation tests. The global financial crisis and Eurozone sovereign debt crises were experienced during the study period. Therefore, employment of a cointegration test regarding structural breaks exhibits importance to obtain more reliable results.

Westerlund and Edgerton (2008) cointegration test considers cross-sectional dependency and structural breaks and permits varying variance and serial correlation. This test also allows breaks in different terms for each country in the intercept and in the slope (trend). The test is derived from the following equation:

$$
\begin{aligned}
& y_{i, t}=\alpha_{i}+{ }_{i} t+\delta_{i} D_{i, t}+x_{i, t}^{\prime} \beta_{i}+\left(D_{i, t} x_{i, t}\right)^{\prime} \gamma_{i}+z_{i, t} ; \\
& x_{i, t}=x_{i, t-1}+w_{i, t},
\end{aligned}
$$

where $i=1,2, \ldots, N$ are the cross-sections; $t=1,2, \ldots, T$ are the time periods.

The dummy $D_{i, t}$ in the equation is as follow:

$$
D_{i, t}=\left\{\begin{array}{l}
1, t>T_{i} \\
0, \text { other }
\end{array} .\right.
$$

Moreover, while $\alpha_{i}$ and $\beta_{i}$ indicate constant and slope (trend) coefficients before the break, $\delta_{i}$ and $\gamma_{i}$ reflect the change after the break. Also, $w_{i, t}$ is the error term. The error term $z_{i, t}$ in Eq. (1) has been obtained by the following equation, allowing for cross-section dependency by using common factors:

$$
\begin{aligned}
& z_{i, t}=\lambda_{i}^{\prime} F_{t}+v_{i, t} ; \\
& F_{i, t}=\rho_{j} F_{j, t-1}+u_{j, t} ; \\
& \phi_{i}(L) \Delta v_{i, t}=\phi_{i} v_{i, t-1}+e_{i, t} .
\end{aligned}
$$

Here, $F_{t}$ and $F_{j, t}$ are defined as conforming vectors of $\mathrm{k}$-dimensional covector $(j=1,2, \ldots$, $k$ ) and $\lambda_{i}$ factor loads. For all $j$, under the assumption of $\rho_{j}<1$ Ft is stationary. Thus, Eq. (1) is cointegrated for $\phi_{i}<0$.

In the presence of cross-sectional dependency, the error term $\hat{S}_{i, t}$ is calculated as in Eq. (6):

$$
\begin{aligned}
& \hat{S}_{i, t}=y_{i, t}-\hat{\alpha}_{i}-\hat{\eta}_{i} t-\hat{\delta}_{i} D_{i, t}-x_{i, t}^{\prime} \hat{\beta}_{i}-\left(D_{i, t} x_{i, t}\right)^{\prime} \hat{\gamma}_{i}-\lambda_{i}^{\prime} \hat{F}_{t} \\
& \Delta \hat{S}_{i, t}=\text { constant }+\phi_{i} \hat{S}_{i, t-1}+\sum_{j=1}^{\rho_{i}} \phi_{i, j} \Delta \hat{S}_{i, t-j}+\text { error. }
\end{aligned}
$$


Westerlund and Edgerton (2008) defined the following statistics to obtain panel cointegration tests in the context of the statistical calculations above:

$$
\begin{aligned}
& L M_{\phi}(i)=T \hat{\phi}_{i}\left(\frac{\hat{\omega}_{i}}{\hat{\sigma}_{i}}\right) ; \\
& \operatorname{LM}_{\tau}(i)=\left(\frac{\hat{\phi}_{i}}{S E \hat{\phi}_{i}}\right),
\end{aligned}
$$

$\hat{\phi}_{i}$ in equality (9) is the OLS estimator of $\phi_{i}$ in equality (10), and $\hat{\sigma}_{i}$ is the estimated standard error. Moreover, $\hat{\omega}^{2}$ is the estimated long-run variance of $\Delta v_{i, t} . S E \hat{\phi}_{i}$ in equality (9) is the estimated standard error of $\hat{\phi}_{i}$. Westerlund and Edgerton (2008) proposed two tests based on $L M_{\phi}(\mathrm{i})$ and $L M_{\tau}(\mathrm{i})$ statistics. These:

$$
\begin{aligned}
& \overline{L M}_{\phi}(N)=\frac{1}{N} \sum_{i=1}^{N} L M_{\phi}(i) ; \\
& \overline{L M}_{\tau}(N)=\frac{1}{N} \sum_{i=1}^{N} L M_{\tau}(i) .
\end{aligned}
$$

As a result, the standardized test statistics are calculated as follows. $Z_{\tau}(N)$ yields robust results in nearly all the cases, but $Z_{\phi}(N)$ provides better results as $T$ increases. Also $Z_{\tau}(N)$ seems very robust in case of serial correlation.

$$
\begin{aligned}
& Z_{\phi}(N)=\sqrt{N}\left(\overline{L M}_{\phi}(N)-E\left(B_{\phi}\right)\right) ; \\
& Z_{\tau}(N)=\sqrt{N}\left(\overline{L M}_{\tau}(N)-E\left(B_{\tau}\right)\right) .
\end{aligned}
$$

The AMG estimator takes notice of the presence of heterogeneity and cross-sectional dependency and is employed in case that all the series are integrated to one, and calculates the cointegrating coefficients for the panel and each cross-section. The panel coefficient is forecasted through weighting the arithmetic means of the cross-section coefficients and in turn produces relatively more robust results in comparison with the ones by Pesaran's (2006) estimator of common correlated effects. The AMG estimator dissociates the variables as follows:

$$
\begin{aligned}
& y_{i t}=\beta_{i}^{y} x_{i t}+u_{i t} ; \\
& u_{i t}=\alpha_{i}+\lambda f_{i} f_{t}+\varepsilon_{i t}(i=1 \ldots N, t=1 \ldots T, m=1 \ldots k) ; \\
& x_{m i t}=\pi_{m i}+\delta_{m i}^{\dot{y}} g_{m t}+\rho_{1 m i} f_{1 m t}+\ldots+\rho_{n m i} f_{n m t}+v_{i t} ; \\
& f_{t}=\tau^{y} f_{t-1}+\varepsilon_{i t} \text { ve } g_{t}=\Psi \dot{y}_{t-1}+\Omega_{i t},
\end{aligned}
$$

where $x_{i t}$ is the vector of observable covariates in the above equations, $f_{t}$ and $g_{t}$ represent the unobserved common factors, and $\lambda_{i}$ represent the country-specific factor loadings.

\section{Empirical analysis}

In the empirical analysis, the pretests of cross-sectional dependence and homogeneity were firstly conducted. The cross-sectional dependence was investigated with Breusch and Pagan (1980) LM, Pesaran et al. (2008) adj. LM and Pesaran (2004) LM CD tests and the results 
are reported in Table 3. The null hypothesis suggesting the cross-sectional independence was denied at $1 \%$ significance level for the first model, but was accepted for the second model, therefore we can assert that we have a cross-sectional dependence among the series of the first model and no cross-sectional dependence among the series of the second model. The existence of cross-sectional dependence indicated that an economic shock in any country from the panel can affect the other countries differently. Therefore utilization of econometric tests regarding cross-sectional dependence enables us to obtain more reliable and consistent results.

Secondly, existence of heterogeneity was investigated using adjusted delta tilde test proposed by Pesaran and Yamagata's (2008) and the findings are disclosed in Table 4. The null hypothesis stating the presence of homogeneity was rejected at the 0.01 significance level. Heterogeneity in the slope coefficients was found. The test results showed that regression coefficients of the variables may vary across each cross-sectional unit.

Taking notice of cross-sectional dependence, the existence of unit root was tested by carrying out CIPS test of Pesaran (2007) and the test results are indicated in Table 5. Our findings indicated that all series were $\mathrm{I}(1)$.

Table 3. Results of cross-sectional dependency tests

\begin{tabular}{|l|c|c|c|c|}
\hline \multicolumn{1}{|c|}{ Test } & \multicolumn{2}{c|}{ Model 1 } & \multicolumn{2}{c|}{ Model 2 } \\
\hline & Test statistic & Probability value & Test statistic & Probability value \\
\hline LM & 193.4 & 0.0000 & 55.7 & 0.4483 \\
\hline LM adj. & 30.41 & 0.0000 & -1.285 & 0.1987 \\
\hline LM CD & 6.177 & 0.0000 & 0.7713 & 0.4405 \\
\hline
\end{tabular}

Table 4. Results of homogeneity tests

\begin{tabular}{|c|c|c|c|c|}
\hline & \multicolumn{2}{|c|}{ Model 1 } & \multicolumn{2}{c|}{ Model 2 } \\
\hline Tests & Test statistic & Probability value & Test statistic & Probability value \\
\hline$\tilde{\Delta}$ & 17.950 & 0.000 & 5.564 & 0.000 \\
\hline$\tilde{\Delta}_{a d j .}$ & 19.749 & 0.000 & 6.184 & 0.000 \\
\hline
\end{tabular}

Table 5. Results of CIPS unit root test

\begin{tabular}{|c|c|c|c|c|c|}
\hline \multicolumn{3}{|c|}{ Model 1} & \multicolumn{3}{|c|}{ Model 2} \\
\hline Variables & Constant & Constant + Trend & Variables & Constant & Constant + Trend \\
\hline FIA & -1.129 & 0.260 & FMA & 0.352 & -0.160 \\
\hline $\mathrm{D}$ (FIA) & $-0.413^{\star \star}$ & $0.079^{*}$ & $\mathrm{D}$ (FMA) & $-4.295^{\star * *}$ & $-1.949^{\star *}$ \\
\hline MOBILE & 0.074 & -0.712 & MOBILE & 0.074 & -0.712 \\
\hline $\mathrm{D}$ (MOBILE) & $-1.835^{\star *}$ & $-1.281^{* * *}$ & D(MOBILE) & $-1.835^{\star *}$ & $-1.281^{\star}$ \\
\hline INTERNET & -0.450 & 0.570 & INTERNET & -0.450 & 0.570 \\
\hline D(INTERNET) & $-1.403^{\star}$ & $0.094^{\star}$ & D(INTERNET) & $-1.403^{\star}$ & $-0.862^{\star}$ \\
\hline
\end{tabular}

Note: According to Schwarz information criterion the optimum lag length is 1 ;

$\left({ }^{* *}\right),\left(^{* *}\right),\left(^{*}\right)$ indicate statistical significance at $1 \%, 5 \%$ and $10 \%$ levels. 
The cointegration relationship between variables was tested by Westerlund and Edgerton (2008) cointegration test given the findings of pretests and structural break during the sample period and results are reported in Tables $6 \mathrm{a}, 6 \mathrm{~b}$. The null hypothesis of no cointegration was rejected for both models for no break and regime shift, therefore a cointegrating relationship between the variables exists. This result signifies the existence of a long-run relationship among the series for both models. Furthermore, the dates of structural breaks verified the significant effect of the global financial crisis, Eurozone sovereign debt crisis and national crises.

Table 6a. Results of Westerlund and Edgerton's (2008) cointegration test (Model 1)

\begin{tabular}{|c|c|c|c|}
\hline \multirow{2}{*}{ Test statistics } & \multicolumn{3}{|c|}{ Model } \\
\hline & No break & Level break & Regime shift \\
\hline$Z_{\phi}(N)$ (p value) & $-1.335(0.091)$ & $-0.294(0.384)$ & $-5.935(0.000)$ \\
\hline$Z_{\tau}(N)$ (p value $)$ & $-2.379(0.009)$ & $1.234(0.891)$ & $-5.081(0.000)$ \\
\hline Countries & & Structural breaks & Structural breaks \\
\hline Bulgaria & & 2005 & 2005 \\
\hline Croatia & & 2003 & 2003 \\
\hline Czech Republic & & 1999 & 1999 \\
\hline Estonia & & 2003 & 2005 \\
\hline Hungary & & 2006 & 1999 \\
\hline Latvia & & 2011 & 2002 \\
\hline Lithuania & & 2010 & 2010 \\
\hline Poland & & 2007 & 2007 \\
\hline Romania & & 2007 & 2007 \\
\hline Slovak Republic & & 1999 & 1999 \\
\hline Slovenia & & 2003 & 2003 \\
\hline
\end{tabular}

Table 6b. Results of Westerlund and Edgerton's (2008) cointegration test (Model 2)

\begin{tabular}{|c|c|c|c|}
\hline \multirow{2}{*}{ Test statistics } & \multicolumn{3}{|c|}{ Model } \\
\hline & No break & Level break & Regime shift \\
\hline$Z_{\phi}(N)$ (p value) & $-1.150(0.025)$ & $0.892(0.814)$ & $-1.208(0.014)$ \\
\hline$Z_{\tau}(N)$ (p value) & $-2.600(0.005)$ & $1.616(0.947)$ & $-1.792(0.037)$ \\
\hline Countries & & Structural breaks & Structural breaks \\
\hline Bulgaria & & 2004 & 2004 \\
\hline Croatia & & 2000 & 2001 \\
\hline Czech Republic & & 1998 & 1998 \\
\hline Estonia & & 2006 & 1998 \\
\hline Hungary & & 2002 & 2012 \\
\hline Latvia & & 1999 & 2000 \\
\hline Lithuania & & 2001 & 2000 \\
\hline Poland & & 1998 & 1999 \\
\hline Romania & & 2012 & 2007 \\
\hline Slovak Republic & & 1998 & 1999 \\
\hline Slovenia & & 2008 & 1999 \\
\hline
\end{tabular}


The cointegration coefficients were estimated through AMG method developed by Teal and Eberhardt (2010) taking into consideration the problem of heterogeneity and crosssectional dependence and findings are reported in Table $7 \mathrm{a}$ and $7 \mathrm{~b}$. The panel cointegration coefficients revealed that mobile cellular subscriptions positively affected financial institutions access, and Internet usage positively influenced financial markets access, but the impact of mobile cellular subscriptions on financial institutions access was very low ( 1 unit change in mobile cellular subscriptions led a 0.0015297 increase in financial institutions access).

Table 7a. Results of cointegration coefficients' estimation (Model 1)

\begin{tabular}{|l|c|c|}
\hline \multirow{2}{*}{ Countries } & \multicolumn{2}{|c|}{ Coefficients } \\
\cline { 2 - 3 } & MOBILE & INTERNET \\
\hline Bulgaria & -0.0009781 & $0.0057334^{* * *}$ \\
\hline Croatia & -0.0005845 & $0.005232^{* * *}$ \\
\hline Czech Republic & $-0.0014063^{* * *}$ & $0.0031437^{* * *}$ \\
\hline Estonia & 0.0026971 & $-0.0068613^{\star *}$ \\
\hline Hungary & $0.000899^{* * *}$ & $0.0010362^{\star * *}$ \\
\hline Latvia & $0.0070361^{* * *}$ & $-0.015668^{* * *}$ \\
\hline Lithuania & $0.0019616^{* * *}$ & $-0.0057749^{* * *}$ \\
\hline Poland & $0.0017598^{* *}$ & $0.0024831^{* *}$ \\
\hline Romania & 0.0027707 & 0.0015606 \\
\hline Slovakia & 0.0002894 & 0.0007042 \\
\hline Slovenia & $0.0023813^{* * *}$ & $-0.0046969^{* * *}$ \\
\hline Panel & $0.0015297^{* *}$ & -0.0011916 \\
\hline
\end{tabular}

Note: $\left({ }^{* *}\right),\left({ }^{* *}\right),\left({ }^{*}\right)$ indicate statistical significance at $1 \%, 5 \%$ and $10 \%$ levels.

Table 7b. Results of cointegration coefficients' estimation (Model 2)

\begin{tabular}{|l|c|c|}
\hline \multirow{2}{*}{ Countries } & \multicolumn{2}{|c|}{ Coefficients } \\
\cline { 2 - 3 } & MOBILE & INTERNET \\
\hline Bulgaria & $0.0001743^{* * *}$ & -0.0002867 \\
\hline Croatia & $0.0018241^{\star}$ & 0.0008272 \\
\hline Czech Republic & $-0.0011025^{* * *}$ & 0.0018362 \\
\hline Estonia & -0.0003618 & 0.0018242 \\
\hline Hungary & $0.0006756^{* * *}$ & 0.0003921 \\
\hline Latvia & -0.0006128 & $0.0053029^{* *}$ \\
\hline Lithuania & 0.0002991 & 0.0004751 \\
\hline Poland & $-0.000922^{\star}$ & 0.0010498 \\
\hline Romania & -0.000037 & -0.0000798 \\
\hline Slovakia & 0.0002537 & 0.00008 \\
\hline Slovenia & 0.0007383 & $0.0168589^{* * *}$ \\
\hline Panel & 0.0000845 & $0.0025709^{*}$ \\
\hline
\end{tabular}

Note: $\left({ }^{* *}\right),\left({ }^{* *}\right),\left(^{*}\right)$ indicate statistical significance at $1 \%, 5 \%$ and $10 \%$ levels. 
The individual coefficients revealed that high levels of financial institutions access can be achieved by increasing mobile cellular subscriptions in countries like Hungary, Latvia, Lithuania, Poland, and Slovenia. On the other side, in the Czech Republic mobile cellular subscriptions negatively affected financial institutions' access. Results also indicated that mobile cellular subscriptions positively affect financial markets access in Bulgaria, Croatia, and Hungary and negatively in the Czech Republic and Poland.

A positive impact of Internet usage rate on financial institutions access was found in Bulgaria, Croatia, Czech Republic, Hungary, and Poland, and on financial markets access in Latvia and Slovenia. The effect of Internet usage rate on financial institutions' access is negative in Estonia, Latvia, Lithuania, and Slovenia.

The empirical analysis revealed that mobile phones and internet development generally had a positive impact on the financial inclusion, the results being similar with the theoretical considerations, but the size of the positive effect was found to be very low. Furthermore, the interaction between mobile phones and Internet development and financial institutions access is relatively more meaningful given the very high share of indirect financing in the financial systems of the countries.

Lastly, the causal interaction between indicators was tested by Dumitrescu and Hurlin (2012) causality test and results are presented in Table 8. The findings disclosed a one-way causality mobile cellular subscriptions to financial institutions access and a two-way interaction between rate of individuals using the Internet and financial institutions access, but no significant interactions between the rate of individuals using the Internet and financial markets access were detected. So, mobile cellular subscriptions had a significant impact on financial institutions access in the short run and the rate of individuals using the Internet and financial markets access feed each other in the short run.

Table 8. Dumitrescu and Hurlin (2012) causality test results

\begin{tabular}{|l|c|c|c|}
\hline \multicolumn{1}{|c|}{ Null Hypothesis } & W-Stat. & Zbar-Stat. & Probability value \\
\hline DMOBILE $\nrightarrow$ DFIA & 4.77462 & 2.93274 & 0.0034 \\
\hline DFIA $\nrightarrow$ DMOBILE & 2.25620 & -0.09266 & 0.9262 \\
\hline DMOBILE $\nrightarrow$ DFMA & 3.26763 & 1.12238 & 0.2617 \\
\hline DFMA $\nrightarrow$ DMOBILE & 2.39111 & 0.06941 & 0.9447 \\
\hline DINTERNET $\nrightarrow$ DFIA & 4.05932 & 2.07345 & 0.0381 \\
\hline DFIA $\nrightarrow$ DINTERNET & 3.97598 & 1.97332 & 0.0485 \\
\hline DINTERNET $\nrightarrow$ DFMA & 2.81129 & 0.57417 & 0.5659 \\
\hline DFMA $\nrightarrow$ DINTERNET & 1.74478 & -0.70704 & 0.4795 \\
\hline
\end{tabular}




\section{Conclusions}

In the last decades, we faced extraordinary progress in information and communication technologies and consequently, a digital revolution in the globalized financial sector was noticed stimulated by the development of mobile phones, personal computers, mobile applications, debit/credit cards. In this context financial services had become a digital industry and mobile phones and Internet expansion is expected to improve financial inclusion through easing access to financial services, decreasing the transaction costs and information asymmetry, playing a major role in reducing poverty and income inequality. In this context, the paper empirically analyzed the influence of mobile phone and Internet penetration on financial inclusion, being one of the early empirical studies that focused on this relationship.

Our results revealed that the expansion of mobile phones and Internet use had a significant positive influence on financial inclusion proxied by financial institutions' access and financial markets access in both the short and long run. But the effect of these variables on financial institutions access is more meaningful when it is taken into consideration that the share of indirect finance is higher than direct finance. In this context, mobile cellular subscriptions positively affect financial institutions' access in overall panel and also in Hungary, Latvia, Lithuania, Poland, and Slovenia. Furthermore, the rate of Internet usage, positively affects financial institutions access in Bulgaria, Croatia, Czech Republic, Hungary, and Poland, but the effect size was found to be very weak in the panel.

Financial market access was positively affected by mobile cellular subscriptions in countries like Bulgaria, Croatia, and Hungary and by Internet usage rate in Latvia and Slovenia.

This study indicates that mobile phones and Internet development had a positive weak effect on financial inclusion, considered to be an important factor for financial development, poverty alleviation and income inequality improvement in post-communist EU countries. In this regard, institutional and regulatory arrangements enhancing the people's reliance on electronic and mobile financial services can raise financial inclusion and in turn can become a good promoter of economic growth, poverty alleviation, and income inequality reduction.

Although many people around the world still don't have a bank account and many of them have low incomes we can stimulate financial inclusion by expanding access to both mobile phone and Internet services. Special attention must be paid to the electronic security challenges. A legal framework is required to support the online transactions and payments and safe and secure payment mechanisms need to be provided to assure customers that their information is safe.

The main limitation of our research is the sample size, our study being focused on 11 post-communist EU countries. Concerning future research, it will be useful to increase the sample size by incorporating countries with different levels of development from different regions of the world. Also, future studies can use a multidimensional index to capture financial inclusion that takes into consideration all three dimensions of this concept: usage, access and quality. It will be also interesting to analyse and understand the demand factors that increase the speed of financial inclusion.

We must be aware that problematic of financial inclusion is not entirely solved in developed countries. As we already specified, financial exclusion is not only a problem of the developing economies, it is a global problem. Vulnerable categories of the population from 
developed countries are the most exposed to this phenomenon and a special category of non-nationals (asylum seekers, refugees) must receive increased attention to gain access to financial services.

Even in the most developed economies, there is a continual need to elaborate strategies for supporting people to overcome barriers to basic financial services. In this context financial inclusion strategies that can ensure adequate and convenient financial services available to vulnerable categories of population, especially to non-nationals must be adopted at national or EU level.

\section{Funding}

The publication of this article was partially supported by the 2020 Development Fund of the Babeş-Bolyai University/Publicarea acestui articol a fost finantata partial prin Fondul de Dezvoltare al Universitatii Babes-Bolyai 2020 and partially by other funds of the BabeşBolyai University.

\section{Author contributions}

All authors have contributed significantly to this research in all phases and sections.

\section{Disclosure statement}

Authors have no conflicts of interest to disclose.

\section{References}

Akileng, G., Lawino, G. M., \& Nzibonera, E. (2018). Evaluation of determinants of financial inclusion in Uganda. Journal of Applied Finance \& Banking, 8(4), 47-66.

Alshubiri, F., Jamil, S. A., \& Elheddad, M. (2019). The impact of ICT on financial development: Empirical evidence from the Gulf Cooperation Council countries. Applications of Electronic Finance and Global Technology Readiness. International Journal of Engineering Business Management, 11, 1-14. https://doi.org/10.1177/1847979019870670

Alt, R., Beck, R., \& Smits, M. T. (2018). FinTech and the transformation of the financial industry. Electronic Markets, 28(3), 235-243. https://doi.org/10.1007/s12525-018-0310-9

Aminuzzaman, S., Baldersheim, H., \& Jamil, I. (2003). Talking back! Empowerment and mobile phones in rural Bangladesh: A study of the village phone scheme of Grameen Bank. Contemporary South Asia, 12(3), 327-348. https://doi.org/10.1080/0958493032000175879

Ammar, A., \& Ahmed, E. M. (2016). Factors influencing Sudanese microfinance intention to adopt mobile banking. Cogent Business \& Management, 3(1), 1-20. https://doi.org/10.1080/23311975.2016.1154257

Anarfo, E. B., Abor, J. Y., Osei, K. A., \& Gyeke-Dako, A. (2019). Financial inclusion and financial sector development in Sub-Saharan Africa: A panel VAR approach. International Journal of Managerial Finance, 15(4), 444-463. https://doi.org/10.1108/IJMF-07-2018-0205

Andrianaivo, M., \& Kpodar, K. (2012). Mobile phones, financial inclusion, and growth. Review of Economics and Institutions, 3(2), 1-30. https://doi.org/10.5202/rei.v3i2.75 
Arvidsson, N. (2014). Consumer attitudes on mobile payment services - results from a proof of concept test. International Journal of Bank Marketing, 32(2), 150-170.

https://doi.org/10.1108/IJBM-05-2013-0048

Asongu, S. A. (2013). How has mobile phone penetration stimulated financial development in Africa. Journal of African Business, 14(1), 7-18. https://doi.org/10.1080/15228916.2013.765309

Asongu, S. A. (2015). The impact of mobile phone penetration on African inequality. International Journal of Social Economics, 42(8), 706-716. https://doi.org/10.1108/IJSE-11-2012-0228

Asongu, S. A., \& Moulin, B. (2016). The role of ICT in reducing information asymmetry for financial access. Research in International Business and Finance, 38, 202-213. https://doi.org/10.1016/j.ribaf.2016.04.011

Asongu, S. A., \& Nwachukwu, J. C. (2019). ICT, financial sector development and financial access. Journal of the Knowledge Economy, 10, 465-490. https://doi.org/10.1007/s13132-017-0477-x

Asongu, S. A., \& Odhiambo, N. M. (2017). Mobile banking usage, quality of growth, inequality and poverty in developing countries. Information Development, 35(2), 303-318. https://doi.org/10.1177/0266666917744006

Asongu, S. A., Nwachuwku, J. C., \& Aziz, A. (2018). Determinants of mobile phone penetration: Panel threshold evidence from Sub-Saharan Africa. Journal of Global Information Technology Management, 21(2), 81-110. https://doi.org/10.1080/1097198X.2018.1462069

Barboni, G., Cassar, A., \& Demont, T. (2017). Financial exclusion in developed countries: A field experiment among migrants and low-income people in Italy. Journal of Behavioral Economics for Policy, 1(2), 39-49.

Bhuvana, M., Vasantha, S., \& Bharath, R. (2016). Information and Communication Technology (ICT) A drive for financial inclusion. Journal of Chemical and Pharmaceutical Sciences, 9(4), 1885-1889. www.jchps.com

Bisht, S. S., \& Mishra, V. (2016). ICT-driven financial inclusion initiatives for urban poor in a developing economy: Implications for public policy. Behaviour \& Information Technology, 35(10), 817-832. https://doi.org/10.1080/0144929X.2016.1183711

Bold, C., Porteous, D., \& Rotman, S. (2012). Social cash transfers and financial inclusion: Evidence from four countries. (Report No. 77, pp. 1-28). Consultative Group to Assist the Poor. https://www.cgap. $\mathrm{org} / \mathrm{sites} / \mathrm{default} /$ files/Focus-Note-Social-Cash-Transfers-and-Financial-Inclusion-Evidence-fromFour-Countries-Feb-2012.pdf

Bongomin, G. O. C., Ntayi, J. M., Munene, J. C., \& Malinga, C. A. (2018). Mobile money and financial inclusion in Sub-Saharan Africa: The moderating role of social networks. Journal of African Business, 18(4), 361-384. https://doi.org/10.1080/15228916.2017.1416214

Bose, B. K., Patra, A., Dash, S. R., \& Bhujabal, B. (2018). Financial inclusion and economic growth: A critical appraisal for evidence-based policy (EBP). International Journal of Management, Technology and Engineering, 8(12), 2021-2030.

Breusch, T., \& Pagan, A. (1980). The Lagrange multiplier test and its applications to model specification in econometrics. The Review of Economic Studies, 47(1), 239-253. https://doi.org/10.2307/2297111

Caporale, G. M., Rault, C., Sova, A. D., \& Sova, R. (2015). Financial development and economic growth: Evidence from $10 \mathrm{New}$ European Union Members. International Journal of Finance \& Economics, 20(1), 48-60. https://doi.org/10.1002/ijfe.1498

Center for Financial Inclusion. (2018). New Global Findex: 69 percent of global population is banked. https://www.centerforfinancialinclusion.org/new-global-findex-sixty-nine-percent-of-global-population-is-banked

Chatterjee, A., \& Anand, N. (2017). Financial inclusion, information and communication technology diffusion and economic growth: A panel data analysis (Working Paper 165/2017). http://www.mse. ac.in/wp-content/uploads/2017/08/WP-165-1.pdf 
Chinoda, T., \& Kwenda, F. (2019). Do mobile phones, economic growth, bank competition and stability matter for financial inclusion in Africa? Cogent Economics \& Finance, 7(1), 1-20. https://doi.org/10.1080/23322039.2019.1622180

Dittus, P., \& Klein, M. U. (2011). On harnessing the potential of financial inclusion (BIS Working Papers No 347). Basel. https://doi.org/10.2139/ssrn.1859412

Dumitrescu, E., \& Hurlin, C. (2012). Testing for Granger non-causality in heterogeneous panels. Economic Modelling, 29(4), 1450-1460. https://doi.org/10.1016/j.econmod.2012.02.014

Edo, S., Okodua, H., \& Odebiyi, J. (2019). Internet adoption and financial development in Sub-Saharan Africa: Evidence from Nigeria and Kenya. African Development Review, 31(1), 144-160. https://doi.org/10.1111/1467-8268.12370

Farhadi, M., Ismail, R., \& Fooladi, M. (2012). Information and communication technology use and economic growth. PloS One, 7(11), e48903. https://doi.org/10.1371/journal.pone.0048903

Gosavi, A. (2018). Can mobile money help firms mitigate the problem of access to finance in Eastern sub-Saharan Africa. Journal of African Business, 19(3), 343-360. https://doi.org/10.1080/15228916.2017.1396791

Grohmann, A., Klühs, T., \& Menkhoff, L. (2018). Does financial literacy improve financial inclusion? Cross country evidence. World Development, 111, 84-96. https://doi.org/10.1016/j.worlddev.2018.06.020

Haupert, V., Maier, D., \& Müller, T. (2017). Paying the price for disruption: How a FinTech allowed account takeover. In Proceedings of the $1^{\text {st }}$ Reversing and Offensive-oriented Trends Symposium. https://doi.org/10.1145/3150376.3150383

House of Lords. (2017). Tackling financial exclusion: A country that works for everyone? (Report of Session 2016-17). Select Committee on Financial Exclusion. https://publications.parliament.uk/pa/ ld201617/ldselect/ldfinexcl/132/132.pdf

Hussaini, U., \& Chibuzo, I. (2018). The effects of financial inclusion on poverty reduction: The moderating effects of microfinance. International Journal of Multidisciplinary Research and Development, 5(12), 188-198.

Irving Fisher Committee. (2015). Proceedings of the Workshop on "Financial Inclusion Indicators", cohosted by the Bank Negara Malaysia, Sasana Kijang, Kuala Lumpur, 5-6 November 2012. IFC Bulletins No. 38, Bank for International Settlements.

Kang, H. (2018). Advancing financial deepening and inclusion. In L. E. Breuer, J. Guajardo, \& T. Kinda (Eds.), Realizing Indonesia's economic potential (pp. 229-248). International Monetary Fund. https:// www.elibrary.imf.org/doc/IMF071/24870-9781484337141/24870-9781484337141/Other_formats/ Source_PDF/24870-9781484355954.pdf

Kirui, O. K., Okello, J. J., Nyikal, R. A., \& Njiraini, G. W. (2013). Impact of mobile phone-based money transfer services in agriculture: evidence from Kenya. Quaterly Journal of International Agriculture, 52(2), 141-162.

Klapper, L., El-Zoghbi, M., \& Hess, J. (2016). Achieving the sustainable development goals: The role of financial inclusion. CGAP. https://www.cgap.org/sites/default/files/Working-Paper-AchievingSustainable-Development-Goals-Apr-2016_0.pdf

Kopala, M. R. (2010). Mobile banking: A tool of financial inclusion for India. https://doi.org/10.2139/ssrn.1674328

Kulesz, O. (2016). The impact of digital technologies on the diversity of cultural expressions in Spain and Hispanic America. UNESCO, Paris. https://en.unesco.org/creativity/sites/creativity/files/ sessions/10igc_inf4_the_impact_of_digital_technologies_octavio_kulesz_en.pdf

Lapukeni, A. F. (2015). Financial inclusion and the impact of ICT: An overview. American Journal of Economics, 5(5), 495-500. 
Lenka, S. K., \& Barik, R. (2018). Has expansion of mobile phone and Internet use spurred financial inclusion in the SAARC countries? Financial Innovation, 4(1), 5. https://doi.org/10.1186/s40854-018-0089-X

Lundqvist, M., \& Erlandsson, F. (2014). The diffusion of mobile phones and its impact on financial inclusion and economic growth in Africa [Master Thesis]. Department of Economics, School of Economics and Management, Lund University.

Majeed, M. T. (2017). Quality of institutions and inclusive financial development in the Muslim World. Financial inclusion and poverty alleviation. In M. Zulkhibri \& A. G. Ismail (Eds.), Financial inclusion and poverty alleviation. Perspectives from Islamic institutions and instruments (pp. 3-40). Palgrave Studies in Islamic Banking, Finance, and Economics.

https://doi.org/10.1007/978-3-319-69799-4_1

Maune, A., Matanda, E., \& Mundonde, J. (2020). Does financial inclusion cause economic growth in Zimbabwe? An empirical investigation. Acta Universitatis Danubius. CEconomica, 16(1), 195-215.

Meskoub, M. (2018). Financial services in the EU: Is there a problem of financial exclusion? (ISS Working Papers - General Series 638). International Institute of Social Studies of Erasmus University Rotterdam (ISS), The Hague.

Mtambalika, A., Manda, T. D., Gombachika, H., \& Kunyenje, G. (2016). Branchless banking in rural Malawi: Potential customers' perspective on bank-led mobile banking. In P. Cunningham \& M. Cunningham (Eds.), 2016 IST-Africa Week Conference Proceedings (pp. 1-11). https://doi.org/10.1109/ISTAFRICA.2016.7530701

Mushtaq, R., \& Bruneau, C. (2019). Microfinance, financial inclusion and ICT: Implications for poverty and inequality. Technology in Society, 59, 101154. https://doi.org/10.1016/j.techsoc.2019.101154

Mwangi, J. (2017). Mobile money. In The Report: Kenia 2017.

Naikoo, A. A., Thakur, S. S., Guroo, T. A., \& Lone, A. A. (2018). Development of society under the modern technology - A review. Scholedge International Journal of Business Policy and Governance, 5(1), 1-8. https://doi.org/10.19085/journal.sijbpg050101

Omar, M. A., \& Inaba, K. (2020). Does financial inclusion reduce poverty and income inequality in developing countries? A panel data analysis. Economic Structures, 9, 37. https://doi.org/10.1186/s40008-020-00214-4

Pesaran, M. H. (2006). Estimation and inference in large heterogeneous panels with a multi factor error structure. Econometrica, 74(4), 967-1012. https://doi.org/10.1111/j.1468-0262.2006.00692.x

Pesaran, M. H. (2007). A simple panel unit root test in the presence of cross-section dependence. Journal of Applied Econometrics, 22(2), 265-312. https://doi.org/10.1002/jae.951

Pesaran, M. H., \& Yamagata, T. (2008). Testing slope homogeneity in large panels. Journal of Econometrics, 142(1), 50-93. https://doi.org/10.1016/j.jeconom.2007.05.010

Pesaran, M. (2004). General diagnostic tests for Cross section dependence in panels (IZA Discussion Paper, 1240).

Pesaran, M. H., Ullah, A., \& Yamagata, T. (2008). A bias-adjusted LM test of error cross-section independence. Econometrics Journal, 11(1), 105-127. https://doi.org/10.1111/j.1368-423X.2007.00227.x

Rasheed, B., Law, S. H., Chin, L., \& Habibullah, M. S. (2016). The role of financial inclusion in financial development: International evidence. Abasyn University Journal of Social Sciences, 9, 330-348.

Romaniuk, P., \& Szromek, A. R. (2016). The evolution of the health system outcomes in Central and Eastern Europe and their association with social, economic and political factors: An analysis of 25 years of transition. BMC Health Services Research, 16, 95.

https://doi.org/10.1186/s12913-016-1344-3 
Sahay, R., Čihák, M., N’Diaye, P., Barajas, A., Mitra, S., Kyobe, A., Mooi, Y., \& Yousefi, S. R. (2015). Financial inclusion: Can it meet multiple macroeconomic goals? (IMF Staff Discussion Notes, No. 15/17). International Monetary Fund. https://doi.org/10.5089/9781513585154.006

Scott, S. (2014). ICTs for financial services in Africa. World Bank. https://openknowledge.worldbank. org/handle/10986/19019

Seng, K. (2017). Considering the effects of mobile phones on financial inclusion in Cambodia (PRA Paper 82225). University Library of Munich, Germany.

Sethi, D., \& Acharya, D. (2018). Financial inclusion and economic growth linkage: Some cross country evidence. Journal of Financial Economic Policy, 10(3), 369-385. https://doi.org/10.1108/JFEP-11-2016-0073

Sharma, D. (2016). Nexus between financial inclusion and economic growth: Evidence from the emerging Indian economy. Journal of Financial Economic Policy, 8(1), 13-36. https://doi.org/10.1108/JFEP-01-2015-0004

Siddik, N. A., Ahsan, T., \& Kabiraj, S. (2019). Does financial permeation promote economic growth? Some econometric evidence from Asian countries. SAGE Open, 9(3), 1-13. https://doi.org/10.1177/2158244019865811

Soumaré, I., Tchana Tchana, F., \& Kengne, T. M. (2016). Analysis of the determinants of financial inclusion in Central and West Africa. Transnational Corporations Review, 8(4), 231-249. https://doi.org/10.1080/19186444.2016.1265763

Sultana, B., \& Khan, M. M. R. (2016). Are mobile financial services promoting financial inclusion in Bangladesh? An assessment study (Working paper series: WP No 1623). Research Department, Bangladesh Bank.

Svirydzenka, K. (2016). Introducing a new broad-based index of financial development (IMF Working Paper, WP/16/5). International Monetary Fund. https://doi.org/10.5089/9781513583709.001

Tchamyou, V. S., Asongu, S. A., \& Odhiambo, N. M. (2019b). The role of ICT in modulating the effect of education and lifelong learning on income inequality and economic growth in Africa. African Development Review, 31(3), 261-274. https://doi.org/10.1111/1467-8268.12388

Tchamyou, V. S., Erreygers, G., \& Cassimon, D. (2019a). Inequality, ICT and financial access in Africa. Technological Forecasting and Social Change, 139, 169-184. https://doi.org/10.1016/j.techfore.2018.11.004

Teal, F., \& Eberhardt, M. (2010). Productivity analysis in global manufacturing production (Economics Series Working Papers 515). University of Oxford, Department of Economics. https://ideas.repec. org/p/oxf/wpaper/515.html

Thulani, M., Chitakunye, P., \& Chummun B. Z. (2014). Mobile money as a strategy for financial inclusion in rural communities. Mediterranean Journal of Social Sciences, 5(25), 216-224.

Toader, E., Firtescu, B. N., Roman, A., \& Anton, S. G. (2018). Impact of information and communication technology infrastructure on economic growth: An empirical assessment for the EU countries. Sustainability, 10(10), 3750. https://doi.org/10.3390/su10103750

Trivelli, C. (2013). Social inclusion cannot be achieved without financial inclusion. https://www.cgap.org/ blog/social-inclusion-cannot-be-achieved-without-financial-inclusion

Uddin, A., Chowdhury, M. A. F., \& Islam, M. N. (2017). Determinants of financial inclusion in Bangladesh: Dynamic Gmm \& quantile regression approach. The Journal of Developing Areas, 51(2), 221-237. https://doi.org/10.1353/jda.2017.0041

United Nations Capital Development Fund. (2020). Financial Inclusion and the SDGs. https://www. uncdf.org/financial-inclusion-and-the-sdgs

Vadavadagi, P. K., \& Allagi, R. G. (2014). Financial inclusion through mobile banking a case of India. EPRA International Journal of Economic and Business Review, 2(10), 108-114. 
Van der Wansem, S. (2013). Financial inclusion: Banking on mobile phones? [Master's dissertation]. Wageningen University, The Netherlands. http://edepot.wur.nl/317936

Washington, E. (2006) The impact of banking and fringe banking regulation on the number of unbanked Americans. Journal of Human Resources, XLI, 106-137. https://doi.org/10.3368/jhr.XLI.1.106

Westerlund, J., \& Edgerton, D. L. (2008). A simple test for cointegration in dependent panels with structural breaks. Oxford Bulletin of Economics and Statistics, 70(5), 665-704. https://doi.org/10.1111/j.1468-0084.2008.00513.x

World Bank. (2015). How to measure financial inclusion. https://www.worldbank.org/en/topic/financialinclusion/brief/how-to-measure-financial-inclusion

World Bank. (2017). Global Findex database 2017. https://globalfindex.worldbank.org/

World Bank. (2018). Financial inclusion. https://www.worldbank.org/en/topic/financialinclusion/overview

World Bank. (2019a). Mobile cellular subscriptions (per 100 people). https://data.worldbank.org/indicator/IT.CEL.SETS.P2

World Bank. (2019b). Individuals using the Internet (\% of population). https://data.worldbank.org/indicator/it.NET.user.ZS

World Savings and Retail Banking Institute. (2016). Close to 40 million EU citizens outside banking mainstream. https://www.wsbi-esbg.org/press/latest-news/Pages/Close-to-40-million-EU-citizensoutside-banking-mainstream.aspx 